原著

高龄化の著しい淡路島に括ける高齢者胃癌手術の現状とその問題点 兵庫県立淡路病院外科

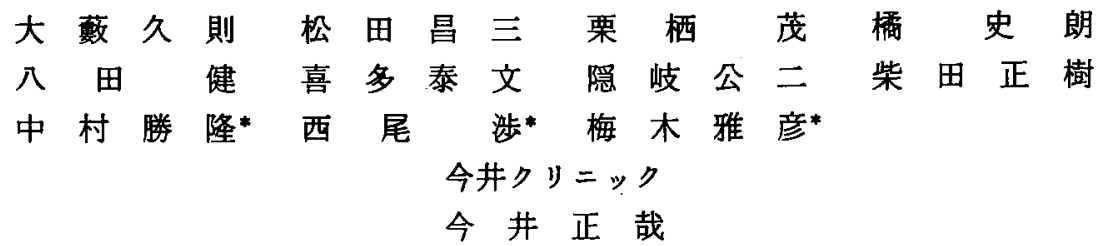

高齢化の著しい淡路島に位置する当院外科に执いては, 最近11年間の胃癌手術症例760 例中70歳代は $31.4 \%, 80$ 歳以上は $5.5 \%$ と高龄者が多くみられた. 術前合併症を有する割 合は70歳末満 $12.1 \% ， 70$ 歳代 $65.3 \% ， 80$ 歳以上 $71.4 \%$ と高龄者ほど高く，70歳未満と70 歳以上の間に有意差がみられた。一方，術後合併症は70歳末満 $19.8 \% ， 70$ 歳代 $20.9 \%$, 80 歳以上 $50.0 \%$ と 80 歳未満と 80 歳以上の間に有意差がみられた。

また，80歳以上の高龄者では80歳未満の症例に比し，入院死亡率でみた手術成績は不 良であり，術後在院日数も有意に長期であった。 さらに, 高齢進行胃癌に対し手術適応 を拡げ，積極的方針で臨んだ最近 3 年間の手術成績は，70歳代は以前に比しむしろ良好 となったが，80歳以上は明らかに不良に終わっていた。このような成績から，胃癌手術 においては80歳以上を高齢者とすべきと考えられた。

索引用語：高龄者胃癌

はじめに

当院の位置する人口 17 万人の淡路島は，若年者人口 都会流出の影響を受け高齢化が著しい(1) -3)．したがっ て，当科で取り报ら症例も高齢者が多く，最近 11 年間 では，胃癌手術症例のうち70歳以上の高齢者か3 $37.0 \%$ と多くみられたので,これら高齢者胃癌手術症例に検 討を加えた。

\section{対象及ひ方法}

1978年 1 月から1988年12月までの11年間の胃癌手術 症例760例を対象とした。そのうち70歳代の高龄者は $31.4 \%, 80$ 歳以上の高秢者は5.5\%であった。高龄で進 行した胃癌症例に対しても手術適応を抬げ，積極的手 術に取り組む方針とした最近の 3 年間をみると70歳代 は32.6\%,80歳以上は $8.9 \%$, 合せて $41.5 \%$ と高龄者の 増加は著しかった(図 1)，これら胃癌手術症例の病期 は stage III, IV の進行胃癌が多数を占めた（表 1 ). このうち70歳以上の高齢者をとりあげ，その臨床像，

* 現神戸大学第 2 外科

1989 年10月19日受付 1990 年 3 月 8 日採用
表 1 病期別症例数

\begin{tabular}{cc}
\hline stage I & 176 例 $(23.2 \%)$ \\
stage II & 103 例 $(13.6 \%)$ \\
stage III & 170 例 $(22.4 \%)$ \\
stage IV & 297 例 $(39.1 \%)$ \\
不 明 & 14 例 $(1.8 \%)$ \\
\hline 計 & 760 例 (100\%) \\
\hline \# 早期癌：133例(リンハ節転移：9例)
\end{tabular}

術前術啳の合併症と手術成績を中心に検討を加之，高 龄者胃癌手術について考察した。

また，最近 3 年間は，高齢者に対して呼吸・感染・ 循環器合併症に対する予防及び治療を中心に細心の術 前・術後管理を行うように努力した（表 2 ）。

有意差検定には $\mathrm{t}$ 㭘定または $\chi^{2}$ 検定を用いた。

\section{臨床成紸}

1）高龄者胃癌の特徵

年齡と病期の関係は表 3 のごとく，70歳代さらに80 歳以上へと高龄者はど stage III・IV の進行症例が多く なる傾向がみられた８0歳以上では，このうち stage 


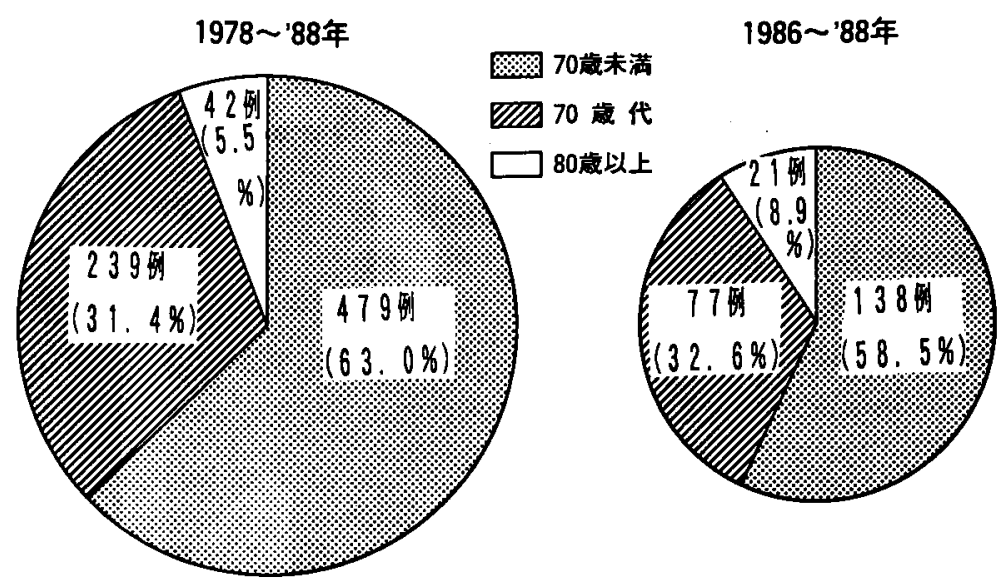

图 1 胃癌手術症例

表 2 高龄者胃演の術前術後管理の要点

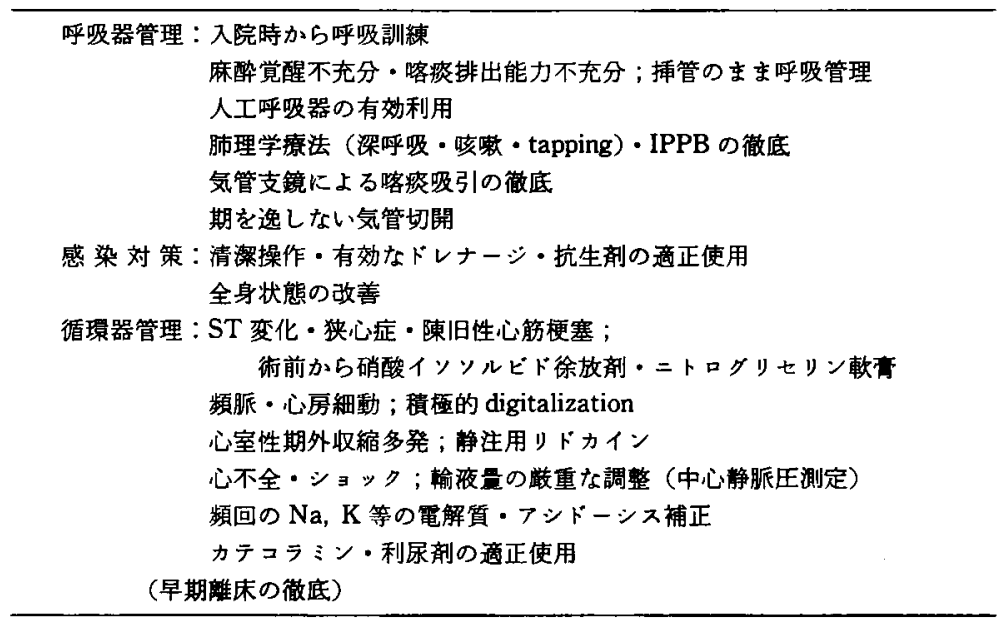

表 3 年数と病期

\begin{tabular}{c|c|c|c|c|c|c}
\hline & stage I & stage II & stage III & stage N & 不 明 & 計 \\
\hline 70 歳末満 & $\begin{array}{c}115 \text { 例 } \\
(24.0 \%)\end{array}$ & $\begin{array}{c}62 \text { 例 } \\
(12.9 \%)\end{array}$ & $\begin{array}{c}99 \text { 例 } \\
(20.7 \%)\end{array}$ & $\begin{array}{c}191 \text { 例 } \\
(39.9 \%)\end{array}$ & $\begin{array}{c}12 \text { 例 } \\
(2.5 \%)\end{array}$ & $\begin{array}{c}479 \text { 例 } \\
(100 \%)\end{array}$ \\
\hline $70 \sim 79$ 歳 & $\begin{array}{c}52 \text { 例 } \\
(21.8 \%)\end{array}$ & $\begin{array}{c}37 \text { 例 } \\
(15.5 \%)\end{array}$ & $\begin{array}{c}57 \text { 例 } \\
(23.8 \%)\end{array}$ & $\begin{array}{c}92 \text { 例 } \\
(38.5 \%)\end{array}$ & $\begin{array}{c}1 \text { 例 } \\
(0.4 \%)\end{array}$ & $\begin{array}{c}239 \text { 例 } \\
(100 \%)\end{array}$ \\
\hline 80 墄以上 & $\begin{array}{c}9 \text { 例 } \\
(21.4 \%)\end{array}$ & $\begin{array}{c}4 \text { 例 } \\
(9.5 \%)\end{array}$ & $\begin{array}{c}14 \text { 例 } \\
(33.3 \%)\end{array}$ & $\begin{array}{c}14 \text { 例 } \\
(33.3 \%)\end{array}$ & $\begin{array}{c}1 \text { 例 } \\
(2.4 \%)\end{array}$ & $\begin{array}{c}42 \text { 例 } \\
(100 \%)\end{array}$ \\
\hline
\end{tabular}

IIIの比率が上昇していた。組織学的記載の明らかな 595例を分析すると，図 2 のごとく，高龄者はど， tub ${ }_{1}$, pap 等の高分化型の比率が高くなり80歳以上と70歳末 満の間に有意差がみられた。さらに por, sig, muc 等 の低分化型の比率は減少し，80歳以上と70歳末満の間
に有意差がみられた。

発生部位の記載の明らかな702例を分析すると, 表 4 のごとく高龄者ほとA 領域を主とする胃癌が多いと いら傾向がみられ，80歳以上と70歳末満との間に有意 差がみられた。 


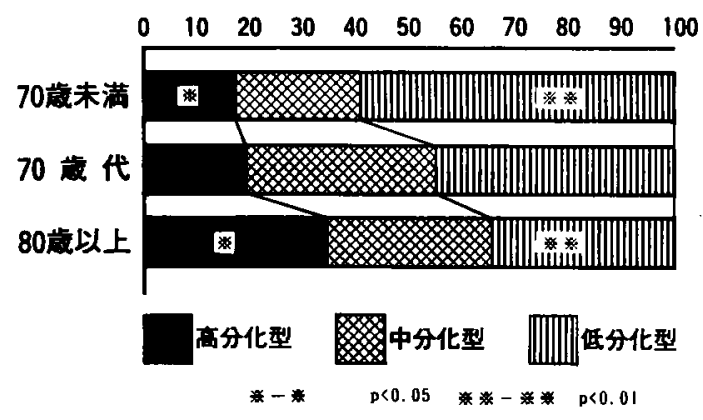

図 2 年龄と組織型

表 4 胃舟発生部位

\begin{tabular}{c|c|c|c|c}
\hline & $\mathrm{C}$ 领域 & $\mathrm{M}$ 領域 & A 領域 & 計 \\
\hline 70 嵅未满 & 63 例 & 167 例 & 211 例 & 441 例 \\
& $(14.3 \%)$ & $(37.9 \%)$ & $(47.8 \%)$ & $(100 \%)$ \\
$70 \sim 79$ 歳 & 24 例 & 87 例 & 113 例 $\mathrm{P}<0.05$ & 224 例 \\
& $(10.7 \%)$ & $(38.8 \%)$ & $(50.4 \%)$ & $(100 \%)$ \\
80 歳以上 & 2 (例 & 10 例 & 25 例 & 37 例 \\
& $(5.4 \%)$ & $(27.0 \%)$ & $(67.6 \%)$ & $(100 \%)$ \\
\hline
\end{tabular}

表 5 年秢と術式

\begin{tabular}{|c|c|c|c|c|}
\hline & 胃切除 & 全摘術 & 伆合術等 & 計 \\
\hline 70歳未満 & $\begin{array}{c}306 \text { 例 } \\
(63.9 \%)\end{array}$ & $\begin{array}{c}121 \text { 例 } \\
(25.3 \%)\end{array}$ & $\begin{array}{c}52 \text { 例 } \\
(10.9 \%)\end{array}$ & $\begin{array}{c}479 \text { 例 } \\
(100 \%)\end{array}$ \\
\hline 70～79歳 & $\begin{array}{c}156 \text { 例 } \\
(65.3 \%)\end{array}$ & $\begin{array}{c}57 \text { 例 } \\
(23.8 \%)\end{array}$ & $\begin{array}{c}26 \text { 例 } \\
(10.9 \%)\end{array}$ & $\begin{array}{c}239 \text { 例 } \\
(100 \%)\end{array}$ \\
\hline 80 歳以上 & $\begin{array}{c}31 \text { 例 } \\
(73.8 \%)\end{array}$ & $\begin{array}{c}5 \text { 例 } \\
(11.9 \%)\end{array}$ & $\begin{array}{c}6 \text { 例 } \\
(14.3 \%)\end{array}$ & $\begin{array}{c}42 \text { 例 } \\
(100 \%)\end{array}$ \\
\hline
\end{tabular}

\section{2. 手術術式}

手術術式は表 5 のごとく，70歳代の胃全摘（以後全 摘と略す）及び幽門側胃切除（以後胃切と略す）は70 歳未満とほぼ同率であったが，80歳以上では，全摘が 少なく，胃切が多くなっていた。治瘁切除率は平均 $65.2 \%$ で各年龄間に差はみられなかった。

3）高獣者の術前合併症

軽度の肝機能障害や腎機能障害を除き，手術を行5 上で障害となる術前合併症は, 循環器合併症 (心電図 異常, 高血圧, 虚血性心疾患)，負血，呼吸器合併症(低 肺機能，喘息，気管支炎)，低蛋白血症の順に多く，全 体として186例 (66.2\%) に341項目の合併症がみられ た（㤗 6).

術前合併症を有する率は，70歳未満，70歳代，80歳 以上と高龄者はど高く，70歳代及び80歳以上は70歳未 満に比し有意に高率であった（表 7 ）。
表 6 高龄者合併症 (70歳以上)

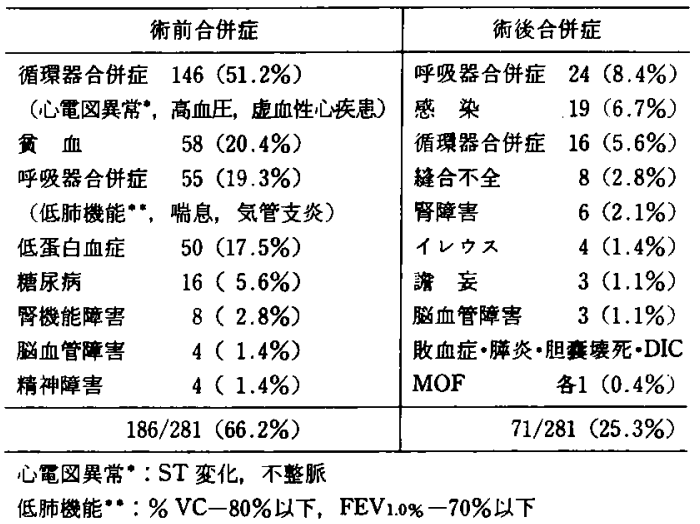

表 7 年龄と合併症

\begin{tabular}{|c|c|c|c|}
\hline & 70歳未満 & $70 \sim 79$ 藏 & 80 歳以上 \\
\hline \multirow[t]{2}{*}{ 衍前合併症 } & $\begin{array}{c}58 / 479 \\
(12.1 \%)\end{array}$ & $\begin{array}{c}156 / 239 \\
(65.3 \%)\end{array}$ & $\begin{array}{c}30 / 42 \\
(71.4 \%)\end{array}$ \\
\hline & $L^{L} \mathbf{F}$ & $\begin{array}{l}1-1 \\
-P<0.01 \mathrm{~L}\end{array}$ & \rfloor \\
\hline \multirow[t]{2}{*}{ 術後合併症 } & $\begin{array}{c}95 / 479 \\
(19.8 \%)\end{array}$ & $\begin{array}{c}50 / 239 \\
(20.9 \%)\end{array}$ & $\begin{array}{c}21 / 42 \\
(50.0 \%)\end{array}$ \\
\hline & L & \multicolumn{2}{|c|}{$\llcorner-P<0.01-$} \\
\hline
\end{tabular}

\section{4）高龄者の術後合併症}

何等かの治療を要した術後合併症は, 呼吸器合併症, 感染 (肺炎·程合不全は除く), 循環器合併症, 稢合不 全の順に多く，全体として71例 (25.3\%) に88項目の 合併症がみられた。

呼吸器合併症の内訳は, 呼吸不全, 去痰困難, 肺炎, 喘息, 無気肺等であり, 術前低肺機能を有した症例に 多くみられた，感染の内訳は，創感染，腹腔内感染，

真菌感染であった. 偱環器合併症の内訳は, 頻脈や心 室性及び心房性期外収樎の不整脈，心不全，高血圧， ショック等であった(表 6 )。街後合併症の発生率は80 歳以上が70歳代及び70歳未満に比し有意に高かった （表 7 ).

\section{5）手術成績と死亡症例の検討}

術後30日以内の手術死亡率は，各年龄熷で差がみら れなかった。しかし，手術死亡を含めた入院死亡率は， 80 歳以上が70歳代，70歳未満に比し 2 倍以上の高率で あった（表 8).

70歳以上高龄齢者入院死亡症例をみると, 呼吸器合 併症から敗血症や心不全, 腎不全を併発して死亡した 症例が 5 例, 縫合不全より重症化した症例が 2 例, 感 


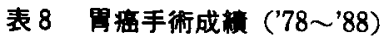

\begin{tabular}{c|c|c|c}
\hline & 70 歳未満 & $70 \sim 79$ 歳 & 80 歳以上 \\
\hline 手術死亡 & $14 / 479$ & $7 / 239$ & $1 / 42$ \\
& $(2.9 \%)$ & $(2.9 \%)$ & $(2.4 \%)$ \\
入院死亡 & $19 / 479$ & $10 / 239$ & $4 / 42$ \\
& $(4.0 \%)$ & $(4.2 \%)$ & $(9.5 \%)$ \\
\hline
\end{tabular}

染源不明の腹腔内膿瘍から悪化した症例が 2 例, 真菌 敗血症から呼吸不全となった症例が1例，不整脈によ る心不全が 1 例, 胆索壊死 1 例, 腸間膜血栓症の疑い 1 例, 原病死 1 例であった. 死亡の原因として, 肺炎・ 腱合不全を加えると，感染が14例中 9 例に関与してい た（表 9 ).

6) 訹後在院日数

最近 3 年間の入院死亡症例を除いた㭪後在院日数 は，80歳以上が70歳代及び70歳未満に比し有意に長 かった（表10）.

7) 最近の 3 年間とそれ以前の 8 年間の対比

1978 1985年の 8 年間（前期と略す）と1985 1988
年の 3 年間（後期と略す）とで対比し，手術成績等に ついて検討した。

後期は, 前期に比し70歳代及び80歳以上の症例の切 除率は有意に上昇してお゙り，根治術の不可能な $\mathrm{P} \cdot \mathrm{H}$ ・ $\mathrm{N}_{4}$ 因子を持つ症例に対する絶対非治瘾切除率す有意 に上昇していた，手術死亡率及び入院死亡率からみた 手術成績は，70歳代では後期のほうがむしろ良好で あったが，80歳以上では後期の手術死亡率は $4.8 \%$ ，入 院死亡率は $19.0 \%$ と明らかに不良となっていた（表 11).

\section{考察}

最近の人口動態統計によれば》日本人男性の平均寿 命は75.54歳, 女性の平均寿命は81.30歳に達したが， 今後さらにその寿命は延長する事が予想される。した がって，高龄者手術症例与今後さらに增加してゆくす のと考えられる.なかです当淡路島では，若年者人口 の都会流出により高齡化は著しく，厚生省統計等(1)-8) によれば，当地の人口はすでに日本の21世紀初頭の年 踰構成を示している．そのような高齢化地域に位置す

表 9 胃癌入院死亡症例の検討（70葴以上）

\begin{tabular}{|c|c|c|c|c|c|c|c|}
\hline No & 年此命 & 性 & 病 期 & 術式 & 術前合併症 & 術後合併症 & 術後 \\
\hline 1) & 71 & 女 & I & 胃切 & 不整脈 & $\begin{array}{l}\text { 肺炎・呼吸不全 } \\
\text { 下梨 }\end{array}$ & 25 日 \\
\hline 2) & 78 & 男 & II & 胃切 & $\begin{array}{l}\text { 再生不良性蔶血 } \\
\text { 不整脈・低蛋白 }\end{array}$ & $\begin{array}{l}\text { 肺炎・出血傾向 } \\
\text { 不整脈 }\end{array}$ & 12日 \\
\hline 3) & 77 & 男 & III & 胃切 & 低肺機能 & $\begin{array}{l}\text { 肺炎・呼吸不全 } \\
\text { 頻脈 }\end{array}$ & 11日 \\
\hline 4) & 77 & 男 & N (他臟器浸潤) & 胃切 & $\begin{array}{l}\text { 不整脈 } \\
\text { 低蛋白 }\end{array}$ & $\begin{array}{l}\text { 腸間膜血栓症 (?) } \\
\text { 肺炎 }\end{array}$ & 18日 \\
\hline 5) & 77 & 男 & III & 胃切 & $\begin{array}{l}\text { 胃癌穿孔 } \\
\text { 腹膜炎 }\end{array}$ & $\begin{array}{l}\text { 肺炎・心不全 } \\
\text { 堅不全 }\end{array}$ & 69日 \\
\hline 6) & 78 & 男 & 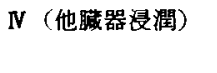 & 胃腸吻合 & $\begin{array}{l}\text { 不整脈 } \\
\text { 低蛋白 }\end{array}$ & 不整脈・ 心不全 & 17日 \\
\hline 7) & 76 & 男 & IV (他臟器浸潤) & 胃切 & 出血 & $\begin{array}{l}\text { 膿㾴・腹膜炎 } \\
\text { 呼吸不全・肝不全 }\end{array}$ & 34日 \\
\hline 8) & 73 & 女 & $\begin{array}{c}\text { N (他澸器浸潤 } \\
\text { 腹膜, 肝転移) }\end{array}$ & 全摘 & $\begin{array}{l}\text { 糖尿病・負血 } \\
\text { 低蛋白 }\end{array}$ & $\begin{array}{l}\text { 縫合不全・腹膜焱 } \\
\text { 右肺䐬穿 }\end{array}$ & 23日 \\
\hline 9) & 84 & 女 & $\begin{array}{c}\text { N (他臟器浸潤 } \\
\text { 腹膜, 肝転移) }\end{array}$ & 全摘 & $\begin{array}{l}\text { 大榷骨骨折・袮創 } \\
\text { 高血压・賓血・不整脈 }\end{array}$ & $\begin{array}{l}\text { 胆蕫壊死 (剖娭) } \\
\text { 頻脈・高血压 }\end{array}$ & 35日 \\
\hline 10) & 77 & 男 & $\begin{array}{c}\text { IV (他䐵器浸潤・ } \\
\text { 腹膜, 肝転移) }\end{array}$ & 胃腸吻合 & 閉塞性黄瘨 & $\begin{array}{l}\text { 肝障害 } \\
\text { (原病死) }\end{array}$ & 58日 \\
\hline 11) & 87 & 男 & $\begin{array}{c}\text { IV (他臓器浸潤 } \\
\text { 腹膜, 肝転移) }\end{array}$ & 全摘 & $\begin{array}{l}\text { 高血圧・喘息・貧血 } \\
\text { 低蛋白血症・不整脈 }\end{array}$ & 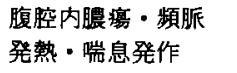 & 45日 \\
\hline 12) & 76 & 男 & III & 全摘 & $\begin{array}{l}\text { 低肺機能・脳梗塞 } \\
\text { 紅皮症・低蛋白 }\end{array}$ & $\begin{array}{l}\text { 䋖合不全·腎不全 } \\
\text { DIC }\end{array}$ & 24日 \\
\hline 13) & 84 & 女 & IV (腹膜, 肝転移) & 胃切 & $\begin{array}{l}\text { 低肺機能・低蛋白 } \\
\text { リンパ球減少 }\end{array}$ & $\begin{array}{l}\text { 真菌敗血症 } \\
\text { 呼吸不全 }\end{array}$ & 8日 \\
\hline 14) & 81 & 男 & I & 胃切 & $\begin{array}{l}\text { 售妄・不整脈・喘息 } \\
\text { 動脈硬化・腎障害 }\end{array}$ & $\begin{array}{l}\text { 喘息発作・呼吸不全 } \\
\text { 心不全・姐不全 }\end{array}$ & 44日 \\
\hline
\end{tabular}


表10 術後在院日数 ('86 ' 88$)$

\begin{tabular}{|c|c|c|c|}
\hline & \multicolumn{3}{|c|}{ 入院死亡は除く } \\
\hline & 70歳末満 & 70～79歳 & 80 歳以上 \\
\hline & & $-\mathrm{P}<0.01$ & $5-15$ \\
\hline 平均 & 21.4 & 21.7 & 30.8 \\
\hline SD & \pm 9.7 & \pm 8.1 & \pm 27.0 \\
\hline $\mathrm{n}$ & 130 & 74 & 17 \\
\hline
\end{tabular}

表11胃雷手術成繒（最近 3 年間とそれ以前の 8 年間の対比)

\begin{tabular}{|c|c|c|}
\hline & '78～'85年 & '86 '88年 \\
\hline \multirow[t]{6}{*}{ 切除率 } & （70歳代） & \\
\hline & $137 / 162$ & $76 / 77$ \\
\hline & $(84.6 \%)-$ & $-(98.7 \%)$ \\
\hline & （80歳以上） & \\
\hline & $15 / 21$ & $-21 / 21$ \\
\hline & $(71.4 \%)$ & $(100 \%)$ \\
\hline \multicolumn{3}{|l|}{$\mathbf{P} \cdot \mathrm{H} \cdot \mathrm{N}_{4}$} \\
\hline \multicolumn{3}{|c|}{ 症例の切除率（70歳代） } \\
\hline & $58 / 94$ & $-54 / 55$ \\
\hline & $(61.7 \%)$ & $(98.2 \%)$ \\
\hline \multicolumn{3}{|c|}{ （80歳以上） } \\
\hline & $0 / 3$ & $-4 / 4$ \\
\hline & $(0 \%)$ & $(100 \%)$ \\
\hline \multirow[t]{6}{*}{ 手術死亡率 } & （70歳代） & \\
\hline & $5 / 162$ & $2 / 77$ \\
\hline & $(3.1 \%)$ & $(2.6 \%)$ \\
\hline & (80歳以上) & \\
\hline & $0 / 21$ & $1 / 21$ \\
\hline & $(0 \%)$ & $(4.8 \%)$ \\
\hline \multirow[t]{6}{*}{ 入院死亡率 } & （70歳代） & \\
\hline & $7 / 162$ & $3 / 77$ \\
\hline & $(4.3 \%)$ & $(3.9 \%)$ \\
\hline & (80歳以上) & \\
\hline & $0 / 21$ & $4 / 21$ \\
\hline & $(0 \%)$ & $(19.0 \%)$ \\
\hline
\end{tabular}

る当科の高龄者症例比率の高さや合併症に対する悩み は日本の21世紀の姿を表しているよらにも思える5゙. そこで，そのような当科の高齢者胃癌手術の現状と問 題点に検討を加えたのである.

\section{症例の特徵}

当科における胃癌手術症例の病期をみると全体的に 進行癌が多いが，なかでも70歳代，80歳以上の高龄者 ほど stage III, IV 進行癌症例が多いのが特徽的であっ た.これは，高龄者では移動の自由が少ないことから， 検診を受けず，少々の症状では受診しない人が多く，
撕食不能や出血等の重篤な症状が現れてから家族があ わてて連れてくる場合が多いためであっだ!。このよ うな症例では，手術をしても治撚切除は不可能なこと が多いが，いわばターミナルケアの一環として症状を とり, quality of life の向上を期待して危険を承知で手 術に踏み切らざるを得ない場合が多いと言光る。この ような手術は，極めてリスクが高く予後も不良となら ざるを得ないことから，望ましい姿ではない。したがっ て，当然のことではあるが，まず高跉者における胃癌 の早期発見早期治療の重要性を強調しておきたい。

\section{手術術式}

80歳以上の高龄者に対しても70歳未满，70歳代と同 様, 積極的に手術に取り組んでいるが，80歳以上の高 龄者では全摘症例の比率が他の年踰層と比較して低 かった．切除範囲に関しては，腫掦から充分距離をお くよらこころがけ，さらに術中迅速病理診断で断端の 癌遺残がないことを確認しており，高龄であるがゆえ に全摘を避けるという配慮はしない上5に心がけてい る.にもかかわらず，80歳以上で全摘症例が少ないの は, 一つには高齢者はどA 領域を主とする限局した高 分化型の比率が高かったという事実によると考えられ た。るつつには当科に紹介された 80 歳以上の症例の らち stage IV 症例がもより少なかったことから, 当 院を受診する以前に高龄を理由に，全摘を要する症例 は手術適応からすでに除外されている可能性す考えら れた。

\section{高齡者の合併症と管理}

高龄者胃癌手術の術後管理に関しては，合併症の予 防が重要であると強調したい。

そのなかでも，呼吸器合併症は胃癌手術の場合は上 腹部操作が主となるため, 橋本等的す指摘するごと く，手術成績を左右する最す重要な合併症であり，今

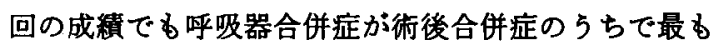
多くみられた。このため，呼吸器合併症に対し，特に 先手先手と予防・治療し，高龄者では後手にまわらな いことが術後管理を成功させるポイントと思われた。

また，この呼吸器合併症の予防治療のためだけでは なく，術後䱿妄の予防・治療のためにも早期離床を促 すことが高龄者では特に大切であるといらことを知っ た. 寸なわち，主治医が患者を支えてでも歩行させる といらよらな努力により, 㴔妄状態に陥り, 呼吸器合 併症をも生じそうになった高齢者の術後をらまく乗り 切れた場合を経験した7).

さらに，術後合併症のらちでも，免疫力の低下した 
高齡者にとって感染は致命的となることが多いの で899), 特に予防と早期治療が必要であることも痛感し た，しかし，感染をコントロールできず死亡した症例 が多く認められたことから，いまだ感染対策という点 に関しては問題が多く残っていると結論せざるを得な かった。

循環器合併症に関しては，高龄者は輸夜の安全域が 狭く、電解質アンパランスで意識障害や不整脈が出や すいため, 細心の管理に心がけている。すなわち,少な くともCVPを指標にした，開心術後に準じた循環器 管理に努め,これによりほぼ満足する結果を得ている.

とにかく，最近は「合併症は生じる前に，生じた合 併症は大事にいたる前に治療をする」といら姿勢で, つきっきりとるいえる術前術後管理に努めているが， このよらな努力が実ったのか, 1986年からは手術適応 を拡げたにもかかからず，70歳代の手術成績は悪化す るどころかむしろ良好となっていた。これは，呼吸・ 循環器を中心とした合併症にはよく対処できるように なったためとも考えられた。

手術成績と死亡症例の検討及び術後在院日数

手術の安全性は術前および術後の全身管理の進歩, 高龄者の体力向上等により高まったと考兄られる。た しかに70歳代の高龄者胃癌手術症例では, 術前の合併 症は多く認められるすのの術後の合併症に関しては70 歳末満症例と変わらず, 順調に経過する症例が多く, 手術成績も劣ってはいない，このよ5に当科の70歳代 の胃癌手術成績が良好となっているのは，高龄化とと あに過疎化の進んだ当地域においては労働力が不足し がちであるため，70歳代は未だ現役として働かなけれ ばならず5，それがかえって体力の衰光，老化を防ぎ， 70歳代高齢者の体力向上につながったためとも考兵号 れた。 しかし，80歳以上胃癌症例では，手術成績は明 らかに不良であった。これは，80歳以上の高齢者では やはり, 各葴器の予備力の低下や免疫能の低下が著明 で,術前合併症を有する率は各年龄層の中で最も高く， 術後合併症 $50.0 \%$ と高率に認められ, 術後合併症が 一旦重篤化するといかに治療しても改善されず逆に次 の合併症を引き起こし，さらに重篤化していったため と考えられた。

㨫後在院日数をみると，80歳以上は70歳代，70歳未 満に比し有意に長期の入院を要していた。これは，術 後経過が良好かにみえる症例でも，80歳以上の高柃者 ではどうしても回復が遅く，退院をでに長期間を要し たためであった。このよらな当科の成績からみると，
高龄者胃癌手術を述べる際には，今後80歳以上を高龄 者とすべきであろらと考えられた。

前期と後期の対比及びその問題点

後期は前期に比し，70墄代では手術成績は悪化せず む乙ろ良好となったものの，80歳以上では手術成績の 明らかな徳化がみられた。すなわち, 高龄進行胃癌に 対する手術適応の拡大に対し，当地の70歳代は充分に 耐術しらるところまで来ているが，80歳以上では未だ 問題が多いと反省させられたのである.

\section{結 語}

人口の高龄化につれ, 高度進行胃癌が増え, それら に対する手術が強いられるといら現象は, 高龄化とと るに過蹯化の進んだ当地特有の姿であり，70歳代まで は充分に耐術しらるという事実す現在の当地に特有の 姿でもあろらが，近い日本の将来の姿の上5にも思わ れる.このため, 高龄化の著しい当地の高齢者胃癌手 術の現状と問題点について検討を加えたのである。

当然ではあるが，高齢者に多い末期胃癌に対して， いわばターミナルケタの一環として苦痛軽减や一時的 な quality of life の向上を目的として行ら非治算切除 手術を強いられるといらことはけけって望ましい姿 ではない，したがって，今後高齢者に対する，より積 極的な胃癌早期発見の必要性を再度強調し稿を終える ものである。

本論文の要旨は第51回日本臨床外科医学会総会 (平成元 年10月）に批いて発表した。

\section{文献}

1）森田和美: 高齢化社会の到来. 兵庫県高龄化白書 一高龄化社会の現況々施策一. 兵庫県, 神戸, 1987, p1-9

2) 厚生省人口問題研究所：日本の将来推計人口, 人 口問題研究所研究資料，244号，1986

3）兵庫県淡路福祉事務所, 淡路地区社会福祉連合 会：老人の福祉, 淡路の福祉' $88,63: 22-29,1988$

4）厚生統計協会：国民衛生の動向，36:80-81,1989

5）松田昌三，沢田勝宽，栗栖 茂：淡路島とい5高龄 化地域に拉ける高龄者手術の現状とその問題点, 日臨外医会誌 $50: 1-10,1989$

6）橋本 整，山城守也，中山夏太郎他：高龄者胃癌 (80歳以上)の問題点一非手術例との対比において 一, 日臨外医会誌 $49: 1347-1351,1988$

7）松田昌三, 梅木雅彦, 喜多泰文他：高齢者の救急手 行とその管理, 岡田昌義, 中村和夫編, 最近救急治 療マニニアル,メディカ出版, 大阪, 1990

8）日置紘士郎, 中根恭司, 平松義文他：胃癌胃全摘術 に拈ける問題点とその対策, 外科治療 $58: 423$ $-428,1988$

9）玉熊正说，望月秀隆，小野 誜：高龄者外科の現 況, 外科治療 $58: 384-390,1988$ 


\title{
SURGICAL PROBLEMS OF GASTRIC CANCER IN THE AGED IN AWAII-ISLAND ASSOCIATED WITH AN AGING POPULATION
}

\author{
Hisanori OHYABU, Shouzou MATSUDA, Shigeru KURISU, Shirou TACHIBANA, Takeshi HATTA, \\ Yasubumi KITA, Kouji OKI, Masaki SHIBATA, Masaya IMAI, \\ Masataka NAKAMURA, Wataru NISHIO and Masahiko UMEKI \\ Department of Surgery, Hyougo Prefectural Awaji Hospital
}

In our department, located in Awaji-island in the midst of an aging district, 760 patients operated on for gastric cancer during the recent 11 years included many aged people; i.e. over 70 years of age $31.4 \%$, and over 80 years of age $5.5 \%$. With an increase in age, patients tend to have more preoperative complications, as shown in the following figures: $12.1 \%$ in patients under 70; 65.3\% in patients in their 70s; and $71.4 \%$ in those of 80 and over. There was a significant difference between the two age groups of under 70, and 70 and over. Postoperative complications developed in $19.8 \%$ of the age group under 70 ; in $20.9 \%$ of that of the $70 \mathrm{~s}$; and in $50.0 \%$ of that of 80 and over, showing a significant difference between the two groups bordering on the age of 80 . Compared to the patient group under 80 , aged patients of 80 and over had poorer surgical results in the mortality rate during hospitalization, and a significantly prolonged hospital stay. Moreover, from an analysis of data for the recent 3 years, our guideline to employ an active attitude for surgery of advanced gastric cancer in aged patients was highly successful in patients in their 70s but was clearly unsuccessful in those in their 80 s and over, compared with former results prior to our guideline. These findings indicate that in operation for gastric cancer patients of 80 years of age and over, should be termed as "the aged". 